\title{
Adaptation of forced migrant children in general educational institutions: a case study of primary school-aged children from Ukraine
}

\author{
Vsevolod V. Konstantinov, Natalya A. Mali \\ Penza State University \\ 40 Krasnaya St, Penza, 440026, Russian Federation
}

\begin{abstract}
The unstable situation in the modern world leads to an ever-increasing number of forced migrants in Russia from different regions. In most cases, forced migration is a critical, traumatic, extreme and frustrating situation. The events in Ukraine caused the emergence in Russia of forced migrants, including school-aged children, who were given the opportunity to continue their education in Russian schools. It can be assumed that the stressful traumatic situation, in which these children found themselves, negatively affected their physical and mental state, which in the future may affect the process of their school adaptation. Studying the specifics of the school adaptation of children who experienced the stressful traumatic situation of forced migration at the stage of primary general education, it is possible to solve the problem of organising adaptation measures in a general educational institution. The aim of the research was to study the specifics of the adaptation of forced migrant children in general educational institutions (through the example of primary school-aged children from Ukraine). The study involved 241 children, of whom 121 were permanent residents of Penza studying in local educational institutions and 120 were forced migrant children from Ukraine who began their studies in Penza schools. To identify the indicators of the emotional and social-psychological components of their school adaptation, the "Draw-A-Non-Existent Animal" and "DrawA-Family" tests were used; and E. Wagner's "Hand Test" was used for diagnosing aggressiveness. It was revealed that the school adaptation of forced migrant children from Ukraine as compared with that of their Russian peers has certain specific features, which are more evident in the characteristics of its emotional and social-psychological components. The results of the study can be used in organizing psychological and pedagogical support for forced migrant children during the process of their school adaptation.
\end{abstract}

Key words: school adaptation, emotional, social-psychological, and intellectual components of school adaptation, forced migrant children, Ukraine

\section{Introduction}

The problem of migration has not ceased to be relevant for several decades. Migration flows move across countries and continents, and this process is quite constant. The reasons for migration can be classified according to different criteria

(C) Konstantinov V.V., Mali N.A., 2020

(c) () This work is licensed under a Creative Commons Attribution 4.0 International License https://creativecommons.org/licenses/by/4.0/ 
(Dyakova, Grishina, 2016), including geographical location (external or internal), time spent in the country of residence (permanent or temporary), purpose of stay (education, employment, etc.), legality or illegality, or involvement in migration (voluntary or forced).

In some cases, migration is aimed at improving the life of a person; in others, there are prerequisites for the deterioration of its quality. Such examples include forced migration, which, unfortunately, is quite common in these days. In many cases, it results from an unstable situation or a threat to the existence of people, forcing them to become migrants or refugees.

Unfortunately, in modern conditions there is a tendency to the emergence of new "flashpoint areas", local conflicts and wars that create the most uncomfortable living conditions for the local population. As a result, migration flows increase, since resettlement from one country to another can in many cases be the only opportunity to save one's own life and health as well as a way to protect one's family members from the risk of unforeseen destructive events.

Vast experience has been accumulated in modern Russia and abroad in providing psychological support for migrants to help them to integrate in the host society (Gritsenko, Shustova, 2011; Konstantinov, Kovaleva, 2013; Lebedeva, Tatarko, 2013; Birman, Simon, Chan, Tran, 2014; Berry, 2015; Ryabichenko, Lebedeva, 2016; Georgiadou, Morawa, Erim, 2017; and others). Most approaches to organising support for migrants are based on the concept of integration strategies proposed by J. Berry (1997). He proposes four possible migrant adaptation strategies: assimilation, separation, integration and marginalisation. Each of these strategies differs in the degree of personal readiness to interact with another culture. Separation and integration presuppose acquaintance with a new culture and preservation of one's own, assimilation means rejection of one's own culture, whereas marginalisation means denial of a foreign culture. According to T.G. Stefanenko, "genuine adaptation means achieving social and psychological integration into a new culture without losing one's own" (Stefanenko, 2009).

The specific features of the adaptation process in the situation of forced migration are highlighted in the works of L.A. Geidenrikh (2009). According to the author, the experience of migration can become a critical, traumatic, extreme, frustrating situation for a person who often encounters negative experiences of interaction and communication with surrounding people.

V.V. Konstantinov (2013) believes that forced migration leads to a number of social-psychological problems associated with the need to rethink moral values, norms and rules as well as with the mismatch between the real and desired situation in society. Migrants should be psychologically prepared to live in new social conditions, otherwise they may experience various physical and mental stresses, emotional breakdowns, psychosomatic diseases; they may run into family problems.

The situation of migration has a negative mental impact, regardless of whether it is forced or voluntary, as migrants experience stress due to the mismatch of their expectations and reality and the need to adapt to the particular worldview and culture of the host population (Gritsenko, Efremenkova, 2016).

The existing experience in organising support for forced migrants in Russia is associated with the changed political situation in the countries of the former So- 
viet Union. The first refugees in Russia appeared in 1988 after the outrages against the Armenians in Sumgait and Baku (Azerbaijan) and against the Meskhetian Turks in 1989 in Fergana (Uzbekistan). In 1992-1993, many refugees from Tajikistan appeared, due to the civil war in this region, as well as from Azerbaijan and Georgia (South Ossetia). In 1994-1995, the majority of forced migrants arrived from Kazakhstan and Uzbekistan, which was due to the political crisis in these countries, but there were also migrants from Kyrgyzstan, Turkmenistan, Armenia, Latvia and Estonia. In the years that followed the situation somewhat stabilised, but, in general, the migration flows from the CIS countries were characterised by periodic ups and downs.

One of the last migration waves was caused by the political crisis in Ukraine in 2014. The acute situation in the south-east of this country led to the appearance of forced migrants in the Russian Federation and, accordingly, to the emergence of new problems and the search for adequate solutions to them. The specifics of the adaptation of forced migrants from Ukraine have become the subject of numerous studies. It is noted that most migrants from Ukraine who entered Russia during this period have families (Korolenko, Lazareva, 2015), but the position of family members with respect to migration may differ on a number of grounds. Thus, the departure from Ukraine was characterised as forced and intended by one part of migrants and as forced but unintended by the other part. Some families were determined to actively solve their problems and, accordingly, quickly received refugee status or temporary residence permits, while others adhered to a passive position and did not officially formalise their residence status.

Forced migrants from Ukraine experience difficulties with employment, housing and acclimatisation, but it is easier for them to adapt to the cultural environment, since Russian traditions and language are not unfamiliar to them (Panich, Agapova, 2015). This is one of the reasons why they choose Russia as a country of asylum. Other reasons include the availability of relatives and friends in Russia, the assistance of Russian services in organising emergency evacuation from the combat zone, the possibility of personal security and employment, and Russian citizenship possessed by at least one of the family members (Kuznetsova, 2018).

The social-psychological adaptation of migrants is a complex, multilateral and multilevel process, which implies forming a stable positive attitude towards the surrounding reality (Konstantinov, Kovaleva, 2013). If migrants form a stable positive attitude towards the surrounding reality and feel satisfied with their mental state, then aggressive manifestations in their behaviour decrease, and we can assume that the adaptation process is successful.

We can identify several factors that affect the intensity, depth and duration of experiences of the forced migration situation. The factors that facilitate the adaptation of migrants from Ukraine include the general system of cultural and historical values (religion, language, culture) and racial characteristics as well as the multinational population of the Russian Federation (Grishina, Lunin, 2015). Special emphasis should be made on the importance of knowing the language of the host country, since it serves as a means of promoting the formation of ethnic identity among migrants with the surrounding society (Dontsov, Stefanenko, Utalieva, 2012).

The factors contributing to the intensification of negative experiences include the circumstances of departure from the country (e.g. unwillingness and un- 
plannedness), possible life threat in the combat zone, absence of relatives or their being in danger, uncomfortable living conditions and problems with employment, unfavourable relations with the local population and their own attitude to the host country (Gatalskaya, Dzhigankaya, 2016). At the same time, researchers note that the negative emotions that migrants experience increase their attachment to their ethnic group and its traditions (Stefanenko, Tumgoeva, Kotova, 2017).

After analysing the available relevant studies, we can conclude that most often the subject of study is the problem of forced migration observed in adults. But, as already noted, during the armed conflict in southeastern Ukraine, people came to Russia with their whole families, including children. By the beginning of autumn of 2014, all children from the families who decided to stay in Russia had been given the opportunity to go to school and continue their education. Along with the problems of adapting to a new life situation, they were forced to adapt to conditions in an unfamiliar school environment. In our opinion, difficulties in the school adaptation will be experienced by children of different age groups, but we have chosen as the object of our study the specifics of the school adaptation of primary school-aged children. It seems to us useful to pay close attention to this category of schoolchildren and study in more detail the specifics of their school adaptation in conditions of forced migration. The obtained results can be used for developing a program of psychological and pedagogical support for primary school-aged children whose parents are forced migrants from regions with cultural and linguistic traditions similar to those of Russia.

To adjust the theoretical approaches to the study of the specifics of the adaptation process in relation to primary school-aged children from families of forced migrants, a detailed analysis of scientific papers on the issues of school adaptation and forced migration is required. Of particular interest to us are studies that examine various aspects of the adaptation of children from migrant and refugee families, including: factors explaining differences in the mental health of children of migrants and local inhabitants (Stevens, Vollebergh, 2008); risks of suicidal behaviour among migrant teenagers (Chau, Kabuth, Chau, 2016); mental health conditions of migrant children and children of migrant workers in China (Gao, Li, Zou, Cross, Bian, Liu, 2015); symptoms of depression in North Korean refugee adolescents and factors influencing their onset (Park, Lee, Jeon, 2017); problems that arise during the adaptation of children in a new language environment (Umrikhina, 2019), and some others. The problems related to the adaptation in a general educational institution were studied in detail by M.V. Grigoryeva, I.V. Dubrovina (Grigoryeva, 2008; Dubrovina, 2006).

Most researchers hold the opinion that the adaptation of primary school-aged children, whose parents are forced migrants, is associated with the experience of feelings such as depression and alienation, increased anxiety and fears. Contacts with their peers and surrounding people are often broken and accompanied by a sense of strangeness. E.V. Kirdyashova et al. (2016) described three groups of typical psychological difficulties encountered in this category of children. The first group is related to the inability to communicate and violation of the rules and norms of communication; the second group comprises emotional disorders, including childhood fears; and the third group considers other problems, for example, children's health conditions. We believe that all of the above problems are associated with the stressful situation of forced migration. 
Children also experience certain difficulties in the school adaptation, which can be considered as the process of becoming accustomed to new conditions, relationships, environment, regime, requirements, types of activity, rules and norms. We used the concept proposed by M.V. Grigoryeva (2006) as the basis for studying the school adaptation. According to this author, the school adaptation is an organised psychological integrity, including such elements or subsystems as emotional adaptation, intellectual adaptation and social-psychological adaptation.

Thus, after analysing various scientific works, we came to the conclusion that it is necessary to carefully study the specifics of the school adaptation in relation to forced migrant children from regions that are culturally and spiritually close to Russia.

The general hypothesis of our study was the assumption that the school adaptation of forced migrant children (in our case, primary school-aged children from Ukraine) and that of children living in Russia have certain specific features. This assumption was reflected in the following particular hypotheses:

1. The situation of forced migration has an adverse effect on the adaptation of primary school-aged children.

2. The most significant differences in the school adaptation of forced migrant children from Ukraine and their peers living in Russia are found when comparing its emotional and social-psychological components.

\section{Methods}

The research procedure consisted of several stages:

1. At the first stage (October of the 2014-2015 academic year), the following was completed:

- assessment of the indicators of the emotional and social-psychological components of the school adaptation;

- observation and assessment of the specific features of the emotional state of primary school-aged children;

- assessment of the children's proficiency in the basic school subjects according to the programme requirements.

2. At the second stage (February of the 2014-2015 academic year), the indicators of the emotional and social-psychological elements of the school adaptation were reassessed.

3. At the third stage (April - May of the 2014-2015 academic year), the results of the first and second stages were compared and conclusions were drawn.

Participants. The study involved 241 children of primary school age. They were divided into two groups. The first group consisted of children permanently residing in Penza and studying in educational institutions of the city (121 children: 63 boys and 58 girls). The second group included forced migrant children who came from Ukraine and began studying at Penza schools (120 children: 65 boys and 55 girls).

Information about the forced migrant children from Ukraine accepted to school was provided by the Penza Education Department. All the children were distributed to classes according to their age, usually no more than three children of the same age to one class. There were no separate classes for the forced migrant children. This principle was probably chosen as more convenient for teachers and 
other schoolchildren, since the appearance of such a separate class could negatively affect the psychological climate in the school and complicate the work of teachers, leading to the segregation and strangeness of the migrant children. As for the children themselves, it might have been more convenient for them to study in the same class.

As a result, the study involved the first-year schoolchildren from seven classes, second-year schoolchildren from nine classes, third-year schoolchildren from twenty-one class and fourth-year schoolchildren from eleven classes (i.e. a total of 48 school classes). The children per year distribution is shown in Table 1. According to the data obtained, there were 46 first-year schoolchildren (21 from Ukraine, 25 from Russia), 58 second-year schoolchildren (27 from Ukraine, 31 from Russia), 83 third-year schoolchildren (44 from Ukraine, 39 from Russia), and 54 fourthyear schoolchildren (28 from Ukraine, 26 from Russia). In addition, the study involved teachers (a total of 48 people) of the classes where the forced migrant children were studying.

Table 1

Study participants

\begin{tabular}{lcccc}
\hline $\begin{array}{c}\text { School year } \\
\text { (number of groups) }\end{array}$ & $\mathbf{1}^{\text {st }}$ year (7) & $\mathbf{2}^{\text {nd }}$ year (9) & $\mathbf{3}^{\text {rd }}$ year (21) & $\mathbf{4}^{\text {th }}$ year (11) \\
\hline Children from Ukraine & 21 & 27 & 44 & 28 \\
Children from Russia & 25 & 31 & 39 & 26 \\
\hline
\end{tabular}

Techniques. The choice of research methods was determined by the age of the children (Konstantinov, Mali, 2016; Mali, 2017). To identify the indicators of the emotional component of the school adaptation, the "Draw-A-Non-Existent Animal" test (Venger, 2003) was used. Analysing the drawings of the children, the researchers noted the presence or absence of the following indicators of the emotional component: "low mood", "unsociability", "sense of instability", and "anxiety".

The "Hand Test" (Kurbatova, Mulyar, 2001) was used to identify "aggressiveness". Each response was assigned to one of 11 categories and rated at 1 point. The aggressiveness coefficient was calculated according to the formula based on the number of points. If the coefficient value was more than 1 , it was concluded about the increased aggressiveness of the testee.

To identify the indicators of the emotional component of the school adaptation, the "Draw-A-Family" test (Venger, 2003) was used. Analysing the drawings of the children, the researchers noted the presence or absence of the following indicators of the social-psychological component: communicative orientation (to the inner world, to the external social environment, multidirectional), activity (high level, medium level, low level), and self-esteem (adequate, inflated or deflated).

The features of the emotional state of the tested children were observed and assessed by their teachers using D. Stott's observation maps (Gurova, Shlyakhta, Sedova, 1992). The participants were supposed to assess the emotional state of the children by the following indicators: distrust of new people, depression, withdrawal, anxiety (in relation to adults and children), hostility (towards adults and children), and emotional stress. 
Afterwards, the results applying the drawing techniques and conducting the expert survey were encoded in a special way: a positive answer (if an indicator was present) was indicated by the number 1, a negative answer (if an indicator was absent) was indicated by the number 2 . This made it possible to compare the results according to the relevant indicators ("Sense of instability" - "Distrust", "Depression" - "Low mood", "Withdrawal" - "Unsociability", "Anxiety", "Hostility" "Aggressiveness", "Emotional tension" - "Fear") and confirm their accuracy.

To assess the children's proficiency in basic school subjects according to the programme requirements, the expert assessment was used. The experts were the teachers of the classes where the forced migrant children studied. During the expert survey, the teachers had to assess the children's proficiency in the basic educational programme and correlate it with the following scale: a high, medium or low level. Additionally, the experts expressed their opinions on the following issues: whether there were any differences in how the main sections of the primary school programme were studied by the children who came from Ukraine and the children permanently residing in Russia; whether the content and procedure for studying certain sections of the programme differ; whether it will be necessary for the forced migrant children to learn some topics of the programme independently or to relearn them; whether their proficiency in Russian is sufficient.

Statistical methods. To confirm the reliability of the results, we used the following methods of mathematical statistics:

- $\varphi^{*}$-test or angular converting by Fisher (it is Russian modification of Fisher's ratio test by Plokhinsky (1970) which is widely used in Russian psychological research) - to compare the frequency of occurrence of the studied parameters in the studied samples;

- Student's $t$-test - to compare the results obtained in the application of the projective drawing techniques and the expert survey, according to the relevant indicators.

\section{Results and discussion}

The study of the school adaptation of the forced migrant children from Ukraine and their Russian peers revealed some specific features of the process in these two groups of children. Based on the data obtained in the analysis of the projective drawing tests, we determined the indicators of the social-psychological and emotional components of the school adaptation. We attributed the following indicators to the emotional component: "low mood", "fear", "unsociability", "sense of instability", "anxiety", and "aggressiveness" diagnosed by the "Draw-A-Non-Existent Animal" test. The indicators of the social-psychological component include as follows: "communicative orientation", "activity" and "features of self-esteem" diagnosed by the "Draw-A-Family" test.

The indicators of the emotional component of the school adaptation of primary schoolchildren from Russia and Ukraine are presented in Tables 2 and 3.

As we can see in the first part of Table 2 that, at the first stage of the study, as expected, the indicators of the emotional component such as "Low mood", "Fear", "Unsociability", "Sense of instability" and "Aggressiveness" were much more common in the group of the Ukrainian children. At the same time, "Anxiety" was a little 
more common in the group of the Russian children, but the differences are statistically insignificant. In the second part of Table 2, we see that, at the second stage of the study, such indicators as "Low mood", "Fear", "Unsociability", and "Aggressiveness" occurred more often in the group of the Ukrainian children than in the group of their Russian peers. As for "Sense of instability", the differences between both groups were statistically insignificant. And as for "Anxiety", the differences were found at the level of the statistical trend.

Table 2

Frequency of the emotional component of the school adaptation indicators in the groups of the Russian and Ukrainian children

\begin{tabular}{lcccccc}
\hline $\begin{array}{l}\text { Indicators of } \\
\text { the emotional } \\
\text { component }\end{array}$ & \multicolumn{2}{c}{ Stage 1, frequency (\%) } & \multicolumn{2}{c}{ Stage 2, frequency (\%) } \\
\cline { 2 - 7 } & $\begin{array}{c}\text { Russian } \\
\text { children } \\
(N=121)\end{array}$ & $\begin{array}{c}\text { Ukrainian } \\
\text { children }\end{array}$ & $\varphi^{\star}$-test & $\begin{array}{c}\text { Russian } \\
\text { children } \\
(N=120)\end{array}$ & $\begin{array}{c}\text { Ukrainian } \\
\text { children }\end{array}$ & $\varphi^{*}$-test \\
& $12.40 \%$ & $24.20 \%$ & $2.398^{\star *}$ & $10.70 \%$ & $23.30 \%$ & $2.647^{* *}$ \\
\hline Low mood & $26.40 \%$ & $53.30 \%$ & $4.331^{\star \star}$ & $22.30 \%$ & $38.30 \%$ & $2.724^{\star *}$ \\
Fear & $36.40 \%$ & $55.00 \%$ & $2.919^{\star *}$ & $36.40 \%$ & $55.00 \%$ & $2.919^{* *}$ \\
Unsociability & $27.30 \%$ & $46.70 \%$ & $3.144^{\star *}$ & $21.50 \%$ & $30.00 \%$ & 1.514 \\
Sense of instability & $40.50 \%$ & $33.30 \%$ & 1.164 & $39.70 \%$ & $26.70 \%$ & $2.150^{*}$ \\
Anxiety & $62.00 \%$ & $78.00 \%$ & $2.787^{\star *}$ & $57.00 \%$ & $72.00 \%$ & $2.398^{* *}$ \\
Aggressiveness & & & & & &
\end{tabular}

Note. ${ }^{*} p \leq .05,{ }^{* *} p \leq .01$.

\section{Dynamics of the emotional component of the school adaptation indicators} in the groups of the Russian and Ukrainian children

\begin{tabular}{lcccccc}
\hline $\begin{array}{c}\text { Indicators of } \\
\text { the emotional } \\
\text { component }\end{array}$ & \multicolumn{3}{c}{$\begin{array}{c}\text { Russian children, frequency (\%) } \\
\text { (N= 121) }\end{array}$} & \multicolumn{2}{c}{$\begin{array}{c}\text { Ukrainian children, frequency (\%) } \\
\text { (N= 120) }\end{array}$} \\
\cline { 2 - 7 } & Stage 1 & Stage 2 & $\varphi^{\star}$-test & Stage 1 & Stage 2 & $\varphi^{*}$-test \\
\hline Low mood & $12.40 \%$ & $10.70 \%$ & 0.420 & $24.20 \%$ & $23.30 \%$ & 0.170 \\
Fear & $26.40 \%$ & $22.30 \%$ & 0.739 & $53.30 \%$ & $38.30 \%$ & $2.339^{* *}$ \\
Unsociability & $36.40 \%$ & $36.40 \%$ & 0.000 & $55.00 \%$ & $55.00 \%$ & 0.001 \\
Sensation of instability & $27.30 \%$ & $21.5 \%$ & 1.058 & $46.70 \%$ & $30.00 \%$ & $2.680^{* *}$ \\
Anxiety & $40.50 \%$ & $39.70 \%$ & 0.132 & $33.30 \%$ & $26.70 \%$ & 1.115 \\
Aggressiveness & $62.00 \%$ & $57.00 \%$ & 0.793 & $78.00 \%$ & $72.00 \%$ & 1.177 \\
\hline
\end{tabular}

Note. ${ }^{\star} p \leq .05,{ }^{* \star} p \leq .01$.

In the first part of Table 3, we can see that the indicators of the emotional element remained almost unchanged in the group of the Russian children, since the differences between the results of the first and second stages were statistically insignificant. The second part of Table 3 shows that there were significant changes (decrease) in the indicators "Fear" and "Sense of instability" in the group of the Ukrainian children, whereas the results for the other indicators did not change.

The indicators of the social-psychological component of the school adaptation of the primary school-aged children from Russia and Ukraine are presented in Tables 4 and 5 .

In the first part of Table 4, we can see that, at the first stage of the study, the indicator "Communicative orientation (to the external social environment)" is much less common in the group of the Ukrainian children than in the group of their 
Russian peers. The differences between the other indicators were statistically insignificant. The second part of Table 4 shows that, at the second stage of the study, the indicators remained almost unchanged; however, there were significant differences in the indicator "Communicative orientation (to the external social environment)" between the two groups, while changes in the other indicators were insignificant.

Table 4

Frequency of the social-psychological component of the school adaptation indicators in the groups of the Russian and Ukrainian children

\begin{tabular}{lcccccc}
\hline $\begin{array}{l}\text { Indicators of } \\
\text { the social- } \\
\text { psychological } \\
\text { component }\end{array}$ & $\begin{array}{c}\text { Russian } \\
\text { children } \\
(N=121)\end{array}$ & $\begin{array}{c}\text { Ukrainian } \\
\text { children } \\
(N=120)\end{array}$ & $\varphi^{*}$-test & $\begin{array}{c}\text { Russian } \\
\text { children } \\
(N=121)\end{array}$ & $\begin{array}{c}\text { Ukrainian } \\
\text { children } \\
(N=120)\end{array}$ & $\varphi^{*}$-test \\
\hline Communicative orientation & & & & & \\
\hline To the inner world & $9.10 \%$ & $19.20 \%$ & $\mathbf{2 . 2 8 2 *}$ & $9.10 \%$ & $18.30 \%$ & $2.104^{*}$ \\
$\begin{array}{l}\text { To the external social } \\
\text { environment }\end{array}$ & $14.90 \%$ & $5.00 \%$ & $\mathbf{2 . 6 5 5 * *}$ & $15.70 \%$ & $5.00 \%$ & $2.825^{* *}$ \\
Multidirectional & $76.00 \%$ & $75.80 \%$ & 0.039 & $75.20 \%$ & $76.70 \%$ & 0.272 \\
\hline Self-esteem & & & & & \\
\hline Adequate & $61.20 \%$ & $54.20 \%$ & 1.102 & $61.20 \%$ & $60.80 \%$ & 0.062 \\
Deflated & $27.30 \%$ & $35.00 \%$ & 1.288 & $27.30 \%$ & $35.00 \%$ & 1.374 \\
Inflated & $11.60 \%$ & $10.80 \%$ & 0.194 & $18.20 \%$ & $10.80 \%$ & $1.638^{*}$ \\
\hline Activity & & & & & 1.079 \\
\hline High level & $15.70 \%$ & $11.70 \%$ & 0.908 & $16.50 \%$ & $11.70 \%$ & 1.079 \\
Medium level & $68.60 \%$ & $65.80 \%$ & 0.466 & $68.60 \%$ & $65.80 \%$ & 0.466 \\
Low level & $15.70 \%$ & $22.50 \%$ & 1.343 & $14.90 \%$ & $22.50 \%$ & 1.514 \\
\hline
\end{tabular}

Note. ${ }^{*} p \leq .05,{ }^{* \star} p \leq .01$.

Table 5

Dynamics of the social-psychological component of the school adaptation indicators in the groups of the Russian and Ukrainian children

\begin{tabular}{|c|c|c|c|c|c|c|}
\hline \multirow{2}{*}{$\begin{array}{l}\text { Indicators of } \\
\text { the social- } \\
\text { psychological } \\
\text { component }\end{array}$} & \multicolumn{3}{|c|}{$\begin{array}{l}\text { Russian children, frequency (\%) } \\
\qquad(N=121)\end{array}$} & \multicolumn{3}{|c|}{$\begin{array}{l}\text { Ukrainian children, frequency (\%) } \\
\qquad(N=120)\end{array}$} \\
\hline & Stage 1 & Stage 2 & $\varphi^{\star}$-test & Stage 1 & Stage 2 & $\varphi^{\star}$-test \\
\hline \multicolumn{7}{|c|}{ Communicative orientation } \\
\hline To the inner world & $9.10 \%$ & $9.10 \%$ & 0.001 & $19.20 \%$ & $18.30 \%$ & $0.178^{\star}$ \\
\hline $\begin{array}{l}\text { To the external social } \\
\text { environment }\end{array}$ & $14.90 \%$ & $15.70 \%$ & 0.171 & $5.00 \%$ & $5.00 \%$ & 0.001 \\
\hline Multidirectional & $76.00 \%$ & $75.20 \%$ & 0.148 & $75.80 \%$ & $76.70 \%$ & 0.163 \\
\hline \multicolumn{7}{|l|}{ Self-esteem } \\
\hline Adequate & $61.20 \%$ & $61.20 \%$ & 0.000 & $54.20 \%$ & $60.80 \%$ & 1.038 \\
\hline Deflated & $27.30 \%$ & $27.30 \%$ & 1.206 & $35.00 \%$ & $28.30 \%$ & 1.115 \\
\hline Inflated & $11.60 \%$ & $18.20 \%$ & 1.447 & $10.80 \%$ & $10.80 \%$ & 0.001 \\
\hline \multicolumn{7}{|l|}{ Activity } \\
\hline High level & $15.70 \%$ & $16.50 \%$ & 0.171 & $11.70 \%$ & $11.70 \%$ & 0.001 \\
\hline Medium level & $68.60 \%$ & $68.60 \%$ & 0.000 & $65.80 \%$ & $65.80 \%$ & 0.001 \\
\hline Low level & $15.70 \%$ & $14.90 \%$ & 0.171 & $22.50 \%$ & $22.50 \%$ & 0.001 \\
\hline
\end{tabular}

Note. ${ }^{*} p \leq .05,{ }^{* \star} p \leq .01$.

In the first part of Table 5, we see that there were no significant changes in the indicators of the socio-psychological element in the group of the Russian chil- 
dren. In the group of the Ukrainian children, the changes were also statistically insignificant.

The features of the emotional state of the forced migrant children were observed and assessed at the first stage of the study by their teachers using D. Stott's observation maps. To compare the data obtained during the expert survey and after applying the projective drawing techniques, the $t$-test was used. The results are presented in Table 6 .

Comparison between the school adaptation indicators based on drawing techniques

Table 6 and the expert survey in the groups of Russian and Ukrainian children

\begin{tabular}{lcc}
\hline \multicolumn{1}{c}{ School adaptation indicators } & $\begin{array}{c}\boldsymbol{t} \text {-test for the group of } \\
\text { the Ukrainian children }\end{array}$ & $\begin{array}{c}\text { t-test for the group of } \\
\text { the Russian children }\end{array}$ \\
\hline Low mood / Depression & 0.20 & 1.40 \\
Fear / Emotional tension & 1.67 & 0.60 \\
Unsociability / Withdrawal & 1.30 & 1.23 \\
Sensation of instability / Distrust & $2.80^{\star}$ & 0.80 \\
Anxiety / Anxiety & 1.20 & 1.15 \\
Aggressiveness / Hostility & 0.34 & 0.56 \\
\hline
\end{tabular}

Note. ${ }^{\star} p \leq .05,{ }^{\star \star} p \leq .01$

We can observe from the Table 6 that, in the group of the Ukrainian children, significant differences were revealed only in the indicators "Sense of instability" and "Distrust", the remaining differences were statistically insignificant. In the group of the Russian children, the differences between all indicators were insignificant. This suggests that teachers' expert opinions and the data on the drawing techniques are similar. Therefore, the results of applying the drawing techniques can be considered quite reliable.

Based on the results of the expert survey, during which the teachers were supposed to assess the level of proficiency in the basic educational programme among the Ukrainian schoolchildren, it was found that $67 \%$ of them are at an average level, $18 \%$ are at a low level, $15 \%$ are at a fairly high level. When answering additional questions, the experts noted that the content of the programmes in the main subjects generally corresponds to the Russian ones. Some problems are associated with the study of the Russian language, since the children, despite the fact that they speak Russian well enough, have difficulty in using its written version. In a far greater degree, the teachers noted the features of the emotional state of the children and their behaviour in relation to their peers and adults.

\section{Conclusion}

The school adaptation of forced migrant children from Ukraine as compared with their peers from Russia has certain differences, which are more evident in the characteristics of its emotional and social-psychological elements. These differences, in our opinion, are due to the situation of forced migration, which has an adverse effect on the adaptation of primary school-aged children. Schoolchildren from Ukraine, as compared with their peers from Russia, are more often characterised by such manifestations as a low mood, fear, strangeness, sense of instability, and aggressiveness. 
Forced migrant children experience fright or anxiety, which may be due to the by-past stressful situation, presence in the combat zone or fear of the unknown in new circumstances. They are characterised by a low mood, the reason for which may be the experience of negative emotions associated with parting with their relatives and friends due to the situation of forced migration.

Forced migrant children from Ukraine tend to be withdrawn and unsociable: this may be due to the fact that they perceive the new life situation as temporary and hope to return home soon. The sense of instability that they experience can be explained by the fact that they are not confident in their current situation and do not feel safe, which is associated with the rapid changes in their life.

An increased level of anxiety is observed in both Russian and Ukrainian schoolchildren and, if the number of the Ukrainian children, who had this indicator identified, decreases over time, as evidenced by the data of the second stage of the study, the number of the Russian children remains almost unchanged. This, in our opinion, can be explained by various reasons. The anxiety of the Russian schoolchildren, as it seems to us, is associated with the learning process and the need to meet the requirements of surrounding adults, as a result of which it does not decrease much during the school year. The anxiety of the Ukrainian schoolchildren is caused by the conditions of forced migration and experienced traumatic stressful situations, which influenced them to a much greater extent.

Forced migrant children from Ukraine have a higher level of aggressiveness. We associate the reason for their increased aggressiveness with negative emotions caused by the experienced traumatic situation (armed conflict), the consequences of which will be felt for a long time. It is possible that their being close to the active combat zone could become the basis for such an emotional reaction.

As a result of studying the social-psychological indicators of these children's school adaptation, it was found that they are characterised by low self-esteem and orientation to their inner world. After comparing the data and the results of assessing the emotional state of the children based on D. Stott's observation maps, we came to the conclusion that, in most cases, there were no significant differences between them: this to some extent confirms their reliability.

The level of proficiency in the basic educational programme among the Ukrainian schoolchildren was generally assessed as average by their teachers. The specific features of the school adaptation of forced migrant children are most noticeable in their behaviour, emotional states and relationships with their classmates and adults.

The results of the study can be used in organising psychological and pedagogical support for primary school-aged children from families of forced migrants during the process of their school adaptation in the host country.

\section{References}

Berry, J.W. (2015). Global psychology: implications for cross-cultural research and management. Cross Cultural Management, 22(3), 342-355. http://doi.org /10.1108/CCM-032015-0031

Berry, J.W. (2017). Vzaimootnosheniya etnicheskih grupp v polikul'turnyh obshchestvah. In N.M. Lebedeva (Ed.), Mezhkul'turnye otnosheniya na postsovetskom prostranstve (pp. 29-54). Moscow: Menedzher Publ. (In Russ.) 
Birman, D., Simon, C.D., Chan, W.Y., \& Tran, N. (2014). A life domains perspective on acculturation and psychological adjustment: A study of refugees from the former Soviet Union. American Journal of Community Psychology, 53(1-2), 60-72. https://doi.org/10.1007/s10464-013-9614-2

Chau, K., Kabuth, B., \& Chau, N. (2016). Association between suicide ideation and attempts and being an immigrant among adolescents, and the role of socioeconomic factors and school, behavior, and health-related difficulties. International Journal of Environmental Research and Public Health, 13(11), 1070. https://doi.org/10.3390/ijerph13111070

Gao, Q., Li, H., Zou, H., Cross, W., Bian, R., \& Liu, Y. (2015). The mental health of children of migrant workers in Beijing: The protective role of public school attendance. Scandinavian Journal of Psychology, 56(4), 384-390. https://doi.org/10.1111/sjop.12232

Gatalskaya, G.V., \& Dzhiganskaya, K.N. (2016). The phenomenology of experiences and the success of adaptation of forced migrants. Russian Psychological Journal, 13(3), 10-25. https://doi.org/10.21702/rpj.2016.3.1 (In Russ.)

Georgiadou, E., Morawa, E., \& Erim, Y. (2017). High manifestations of mental distress in Arabic Asylum seekers accommodated in collective centers for refugees in Germany. International Journal of Environmental Research and Public Health, 14, 612. https://doi.org/10.3390/ijerph14060612

Geydenrikh, L.A. (2009). Sotsialno-Psikhologicheskie Osobennosti Obshcheniya Detey iz Semey Migrantov i Nemigrantov s Uchitelyami, Odnoklassnikami, Roditelyami: Ph.D. in Psychology Thesis. Rostov-on-Don: South Federal University. (In Russ.)

Grigoryeva, M.V. (2008). Shkolnaya Adaptatsiya: Mehanizmyi i Faktoryi v Raznyih Usloviyah Obucheniya. Saratov: Saratov University Publ. (In Russ.)

Gritsenko, V.V., \& Efremenkova, M.N. (2016). Emotsionalnaya sfera lichnosti migrantov kak indikator predraspolozhennosti ikh k konfliktnomu ili konstruktivnomu povedeniyu. Sotsialny Mir Cheloveka: Conference Proceedings (pp. 244-247). Izhevsk: EGRO Publ. (In Russ.)

Gritsenko, V.V., \& Shustova, N.E. (2011). Sotsialno-Psihologicheskaya Adaptatsiya Detey iz Semey Migrantov. Moscow: Forum Publ. (In Russ.)

Grishina, A.V., \& Lunin, S.L. (2015). Ethnic Identity Types of Russian Youth as an Indicator of a Positive Readiness to Accept the Forced Migrants from Ukraine. Russian Psychological Journal, 12(2), 46-55.

Gurova, E.V., Shlyakhta, N.F., \& Sedova, N.N. (1992). Diagnostika Psikhicheskogo Razvitiya Detey. Moscow: Institut molodezhi Publ. (In Russ.)

Dontsov, A.I., Stefanenko, T.G., \& Utalieva, Zh.T. (2012). Yazyk kak faktor etnicheskoy identichnosti. Voprosy Psikhologii, (4), 75-85. (In Russ.)

Dubrovina, I.V. (Ed.). (2006). Prakticheskaya Psikhologiya Obrazovaniya. Saint Petersburg: Piter Publ. (In Russ.)

Dyakova, E.V., \& Grishina, A.V. (2016). Trudovaya i vynuzhdennaya migratsiya iz Ukrainy. Sotsialno-ekonomicheskie posledstviya. Nauka i obrazovanie. Khozyaystvo i ekonomika. Predprinimatelstvo. Pravo i upravlenie, (11), 10-12. (In Russ.)

Kirdyashova, E.V., Pshenichnikova, N.A., \& Kurkov, V.M. (2016). Kultura mezhlichnostnogo obscheniya u mladshikh shkolnikov iz semey migrantov kak psikhologo-pedagogicheskaya problema. Sotsialno-Psikhologicheskaya Adaptatsiya Migrantov v Sovremennom Mire: Conference Proceedings (pp. 75-83). Penza: PGU Publ. (In Russ.)

Konstantinov, V.V., \& Kovaleva, N.A. (2013). Parting with motherland as a socio-psychological problem of migration. Psikhologicheskii Zhurnal, 34(5), 3-15. (In Russ.)

Konstantinov, V.V., \& Mali, N.A. (2016). Osobennosti psikhologicheskoy adaptatsii mladshikh shkolnikov, vynuzhdenno pokinuvshikh territoriyu Ukrainy. Elementary School, (2), 32-35. (In Russ.)

Konstantinov, V.V., \& Mali, N.A. (2016). Psikhologicheskaya adaptatsiya mladshikh shkolnikov, prozhivayushchikh v Rossii i vynuzhdennyh migrantov. Mir Nauki, 4(4), 17-26. (In Russ.) 
Korolenko, A.S., \& Lazareva, Z.N. (2015). Organizatsiya sotsialnoy pomoshchi v Rossii vynuzhdennym migrantam iz Ukrainy v sovremennykh sotsiokulturnykh usloviyakh. Sotsialnaya rabota - fenomen tsivilizovannogo obshchestva: Conference Proceedings (pp. 48-52). Saransk: N.P. Ogareva MGU Publ. (In Russ.)

Kuznetsova, I.B. (2018). Refugees from Ukraine in Russia: Migration policy and everyday life. The Journal of Social Policy Studies, 16(4), 577-594. https://doi.org/10.17323/7270634-2018-16-4-577-594 (In Russ.)

Kurbatova, T.N., \& Mulyar, O.I. (2001). Proektivnaya Metodika Issledovaniya Lichnosti "Hand-Test": Manual. Saint Petersburg: IMATON Publ. (In Russ.)

Lebedeva, N., \& Tatarko, A. (2013). Multiculturalism and Immigration in Post-Soviet Russia. European Psychologist, 18, 169-178. https://doi.org/10.1027/1016-9040/a000161

Mali, N.A. (2017). Osobennosti Shkolnoy Adaptatsii Detey iz Semey Vynuzhdennykh Migrantov: Ph.D. in Psychology Thesis. Saratov: Chernyshevsky Saratov State University. (In Russ.)

Panich, O.E., \& Agapova, E.E. (2015). Psikhologicheskie proyavleniya adaptatsii vynuzhdennykh migrantov iz Ukrainy. Apriori. Seriya: Gumanitarnye nauki, (3), 47-55. (In Russ.)

Park S., Lee M., \& Jeon, J.Y. (2017). Factors affecting depressive symptoms among North Korean adolescent refugees residing in South Korea. International Journal of Environmental Research and Public Health, 14(8), 912. https://doi.org/10.3390/ijerph14080912

Plohinsky, N.A. (1970). Biometriya. Moscow: MSU Publ. (In Russ.)

Ryabichenko, T.A. \& Lebedeva, N.M. (2016). The impact of value similarity with parents and peers on well-being of children in Russian families in Latvia. Social Sciences and Contemporary World, (2), 121-135. (In Russ.)

Stefanenko, T.G. (2009). Etnopsikhologiya. Moscow: Aspekt-Press Publ. (In Russ.)

Stefanenko, T.G., Tumgoeva, T.A., \& Kotova, M.V. (2017). The Ingush's cultural memory and social identity as a representative of repressed ethnic group. National Psychological Journal, (4), 45-56. https://doi.org/10.11621/npj.2017.0404 (In Russ.)

Stevens G., \& Vollebergh, W. (2008). Mental health in migrant children. Journal of Child Psychology and Psychiatry, 49(3), 276-294. https://doi.org/10.1111/j.1469-7610.2007.01848.x

Umrikhina, E.A. (2019). Deti migrantov v inoyazychnoj srede: Perspektiva rodnogo yazyka. Izuchenie i Prepodavanie Russkogo Yazyka v Raznyh Lingvokul'turnyh Sredah: Conference Proceedings (pp. 575-588). Moscow: RUDN Publ. (In Russ.)

Venger, A.L. (2003). Psihologicheskie Risunochnye Testy: Manual. Moscow: VLADOS-PRESS Publ. (In Russ.)

Article history:

Received: 11 December 2019

Revised: 16 March 2020

Accepted: 15 April 2020

\section{For citation:}

Konstantinov, V.V., \& Mali, N.A. (2020). Adaptation of forced migrant children in general educational institutions: A case study of primary school-aged children from Ukraine. RUDN Journal of Psychology and Pedagogics, 17(2), 273-287. http://dx.doi.org/10.22363/23131683-2020-17-2-273-287

\section{Bio notes:}

Vsevolod V. Konstantinov, Dr. Sc. in Psychology, is Head of the Department "General Psychology", Penza State University (Penza, Russia). ORCID iD: https://orcid.org/0000-00021443-3195. E-mail: konstantinov_vse@mail.ru

Natalya A. Mali, Ph.D. in Psychology, is Associate Professor of the Department "Preschool and Defectological Education", Penza State University (Penza, Russia). E-mail: n.mali2012@yandex.ru 


\title{
Особенности школьной адаптации детей из семей вынужденных мигрантов в условиях общеобразовательного учреждения (на примере младших школьников из Украины)
}

\author{
В.В. Константинов, Н.А. Мали \\ Пензенский государственный университет \\ Российская Федерация, 440026, Пенза, ул. Красная, 40
}

\begin{abstract}
Аннотация. Нестабильная обстановка в современном мире приводит к постоянному появлению в России вынужденных мигрантов из разных регионов. В большинстве случаев вынужденная миграция является кризисной, травматической, экстремальной и фрустрирующей ситуацией. События в Украине стали причиной появления в нашей стране вынужденных мигрантов, в том числе детей школьного возраста, которым была предоставлена возможность продолжить обучение в школах России. Можно предположить, что стрессовая травматическая ситуация, в которой оказались дети, негативно повлияла на их физическое и психическое состояние, что в дальнейшем может отразиться на процессе адаптации к школе. Изучение особенностей школьной адаптации на ступени начального общего образования детей, переживших стрессовую травматическую ситуацию вынужденной миграции, способствует решению проблемы продуктивной организации адаптационных мероприятий в условиях общеобразовательного учреждения. Целью исследования было изучение особенностей школьной адаптации детей из семей вынужденных мигрантов к условиям общеобразовательного учреждения (на примере младших школьников из Украины). В исследовании приняли участие 241 учащийся младшего школьного возраста, из них 121 человек - младшие школьники, постоянно проживающие в Пензе и обучающиеся в образовательных учреждениях города, и 120 детей младшего школьного возраста из семей вынужденных мигрантов из Украины, начавших обучение в школах Пензы. Для выявления показателей эмоционального и социально-психологического элементов адаптации использовались проективные рисуночные методики «Рисунок несуществующего животного», «Рисунок семьи», для диагностики агрессивности был использован «Тест руки» Э. Вагнера. Выявлено, что школьная адаптация детей из семей вынужденных мигрантов из Украины по сравнению с их сверстниками из России имеет определенные различия, которые в большей степени обнаруживаются в особенностях ее эмоционального и социально-психологического элементов. Результаты исследования могут учитываться при организации психолого-педагогического сопровождения процесса школьной адаптации детей из семей вынужденных мигрантов.
\end{abstract}

Ключевые слова: школьная адаптация, эмоциональный, социально-психологический и интеллектуальный элементы школьной адаптации, дети из семей вынужденных мигрантов, Украина

\section{История статьи:}

Поступила в редакцию: 11 декабря 2019 г.

Принята к печати: 15 апреля 2020 г.

\section{Для цитирования:}

Konstantinov V.V., Mali N.A. Adaptation of forced migrant children in general educational institutions: a case study of primary school-aged children from Ukraine // Вестник Рос- 
сийского университета дружбы народов. Серия: Психология и педагогика. 2020. Т. 17. № 2. C. 273-287. http://dx.doi.org/10.22363/2313-1683-2020-17-2-273-287

\section{Сведения об авторах:}

Константинов Всеволод Валентинович, доктор психологических наук, профессор, заведующий кафедрой «Общая психология», Пензенский государственный университет (Пенза, Россия). ORCID iD: https://orcid.org/0000-0002-1443-3195. E-mail: konstantinov_vse@mail.ru

Мали Наталья Александровна, кандидат психологических наук, доцент кафедры «Дошкольное и дефектологическое образование», Пензенский государственный университет (Пенза, Россия). E-mail: n.mali2012@yandex.ru 